\title{
Academic Standards for Developing, Implementing, Evaluating, and Improving Information Science and Technology Baccalaureate Degrees
}

\author{
Elayne Shields-Bryant \\ College of Business and Leadership, \\ Fort Hays State University, Hays, Kansas, USA
}

EShields@fhsu.edu

\section{Executive Summary}

The unprecedented growth, development and implementation of information technology (IT) driven by e-commerce and other technological advances have resulted in an increased demand of technology skilled workers (Reichgelt, Zhang, \& Price, 2002; United States Department of Labor Bureau of Labor Statistics, 2005). In response to degree-dependent employment requirements, academic institutions have fallen prey to the laws of supply and demand. The increased interest in obtaining IT-related positions has prompted students to enroll in IT-related degree programs. The government has supported universities interested in developing such programs by providing grants to build schools and colleges of information sciences and technology (IST). Furthermore, as IST programs grow by leaps and bounds, universities and accreditation organizations have been working to develop guidelines by which to monitor and maintain academic standards.

This study identifies national standards for IST baccalaureate programs in the United States. A survey containing 138 IST standard criteria grouped in 15 categories was sent to 50 individuals affiliated with five IST-related accrediting bodies in the United States: the Accreditation Board for Engineering and Technology (ABET) (2006); the American Library Association (ALA) (2003); American Society for Information Science and Technology (ASIS\&T) (2002); the Business Accreditation Committee (BAC) (2002); and the Computer Sciences Accreditation Board (CSAB) (2001), who served as a panel of experts in the area of IST to identify a theoretical framework for IST degree programs. The results of the survey revealed that all respondents agreed with the IST program standards outlined in this study.

The IST standards categories outlined in this study may be utilized by any academic organization interested in developing, implementing, evaluating, or improving their IST degree program.

Material published as part of this journal, either on-line or in print, is copyrighted by the publisher of the Journal of Information Technology Education. Permission to make digital or paper copy of part or all of these works for personal or classroom use is granted without fee provided that the copies are not made or distributed for profit or commercial advantage AND that copies 1) bear this notice in full and 2) give the full citation on the first page. It is permissible to abstract these works so long as credit is given. To copy in all other cases or to republish or to post on a server or to redistribute to lists requires specific permission and payment of a fee. Contact Editor@JITE.org to request redistribution permission.
Future studies could be conducted to identify degree requirements for virtual or online IST degree programs, graduate degree programs, and/or continuing education IST programs.

Keywords: Information Science and Technology (IST), Information Technology (IT) Education, Standards, Curriculum 


\section{Introduction}

In 2004, approximately two million individuals with a bachelor's degree worked in the fastest growing information sciences and technology (IST)-related professions. Projection statistics indicate that occupations in the IT field are currently, and will continue to be, amongst the fastest growing through 2014, with an average projected rate of growth of $43 \%$ within an eight year period, resulting in approximately 844 thousand new jobs by 2014 (United States Department of Labor Bureau of Labor Statistics, 2005, pp. 75 \& 77) as indicated in Table 1.

Table 1: Fastest Growing Occupations, 2004-2014 in Thousands (extract) (United States Department of Labor Bureau of Labor Statistics, 2005, pp. 75 \& 77)

\begin{tabular}{lcccc}
\hline Occupation & $\mathbf{2 0 0 4}$ & $\mathbf{2 0 1 4}$ & Change & Percent \\
\hline Network Analyst and data communications analyst & 231 & 357 & 126 & 55 \\
Application Software engineers (computer software engi- & & & & \\
neer) & 460 & 682 & 222 & 48 \\
Systems Software engineers (computer software engineer) & 340 & 486 & 146 & 43 \\
Computer network administrators & 278 & 385 & 107 & 38 \\
Database Administrators & 104 & 144 & 40 & 38 \\
Computer Systems analyst & 487 & 640 & 153 & 31 \\
Information systems manager & 280 & 353 & 73 & 26 \\
\hline \multicolumn{1}{c}{ Total Jobs } & 2,180 & 3,047 & 867 & 40 \\
\hline
\end{tabular}

Despite the dot-com crash and overseas outsourcing, IST employees continue to be in demand. With the leveling-off of the "economic boom in the internet and telecommunications industries" (Commission of Professionals in Science and Technology, 2003, p. 1), positions in fields such as IT security, telecommunications, electronic commerce, electronic government, and other Internet functions continue to grow. "Except for a slight slowdown during 2001-2002, the Internet's growth has been consistently dramatic," which is one factor that supports the employment projections (Schneider, 2006, p. 58). Figure 1 illustrates IT-related professional employment data from 1996 through 2005 and the factors impacting employment. Based on these projections, the demand for skilled workers will increase by an average of 105 thousand per year. Furthermore, as the software and information technology industry continues to mature, the prospects of IST careers will continue to evolve, mutate, and expand (Nathan \& Turvey, 2001). In response to the increased demand for educated IST professionals, universities have strived to meet this demand by offering an IST degree program.

The IST undergraduate degree has been described as an interdisciplinary program that evolved and integrates curricula from information science, technology, and organizational behavior degree programs that have established accredited criteria. These programs are computer science and information systems, which are accredited by Computing Accreditation Commission (CAC) (2005), library and information sciences, which are accredited by the American Library Association, (2002), computer engineering technology and information engineering technology, which are accredited by the Technology Accreditation Commission (TAC) (2005), and business administration, which is accredited by the Association to Advance Collegiate Schools of Business (AACSB) (2006) as illustrated in Figure 2: IST Framework and Related Accreditation Organization. 
IST Professional Employment Data

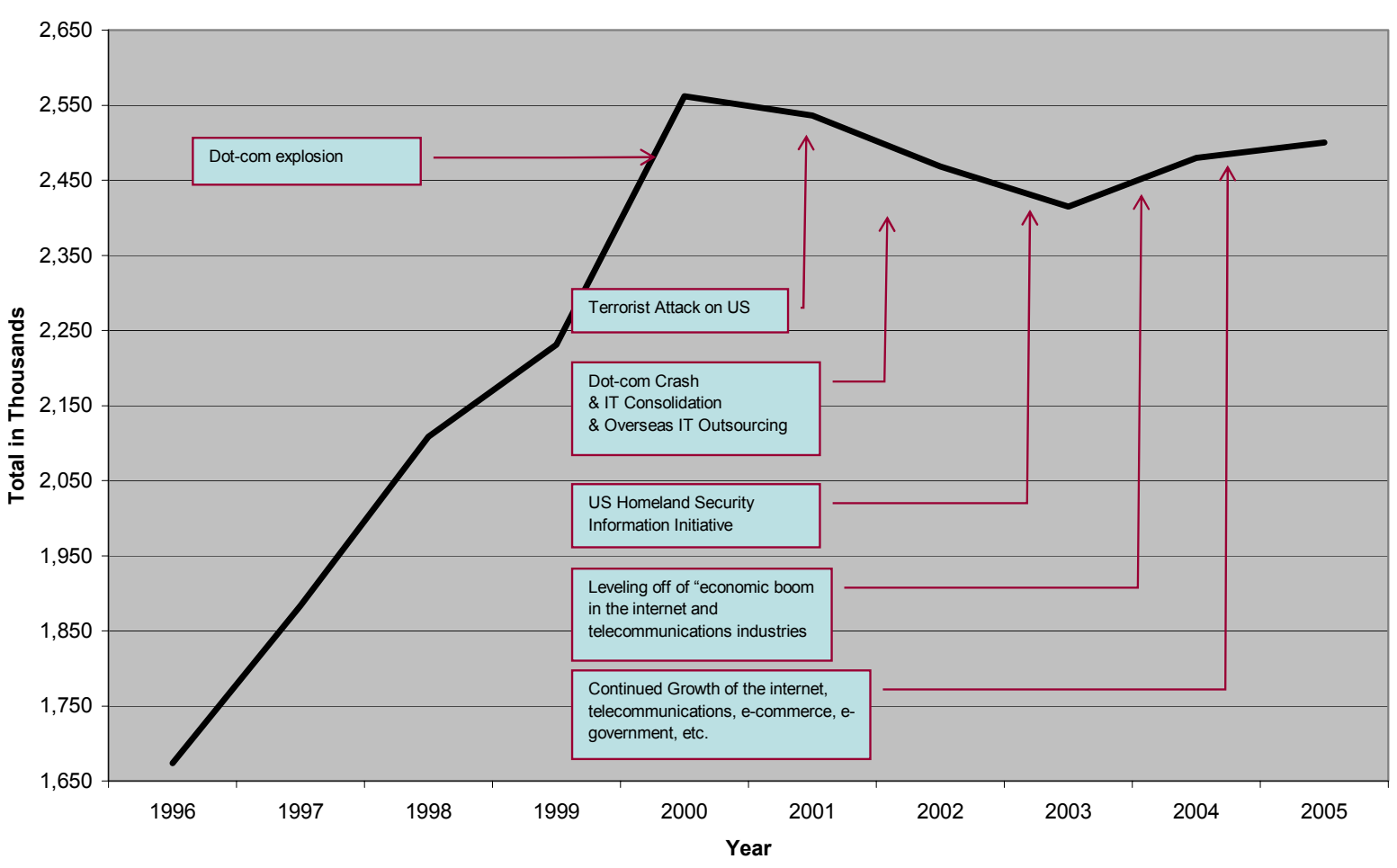

Figure 1: Current IST Professional Employment Statistics

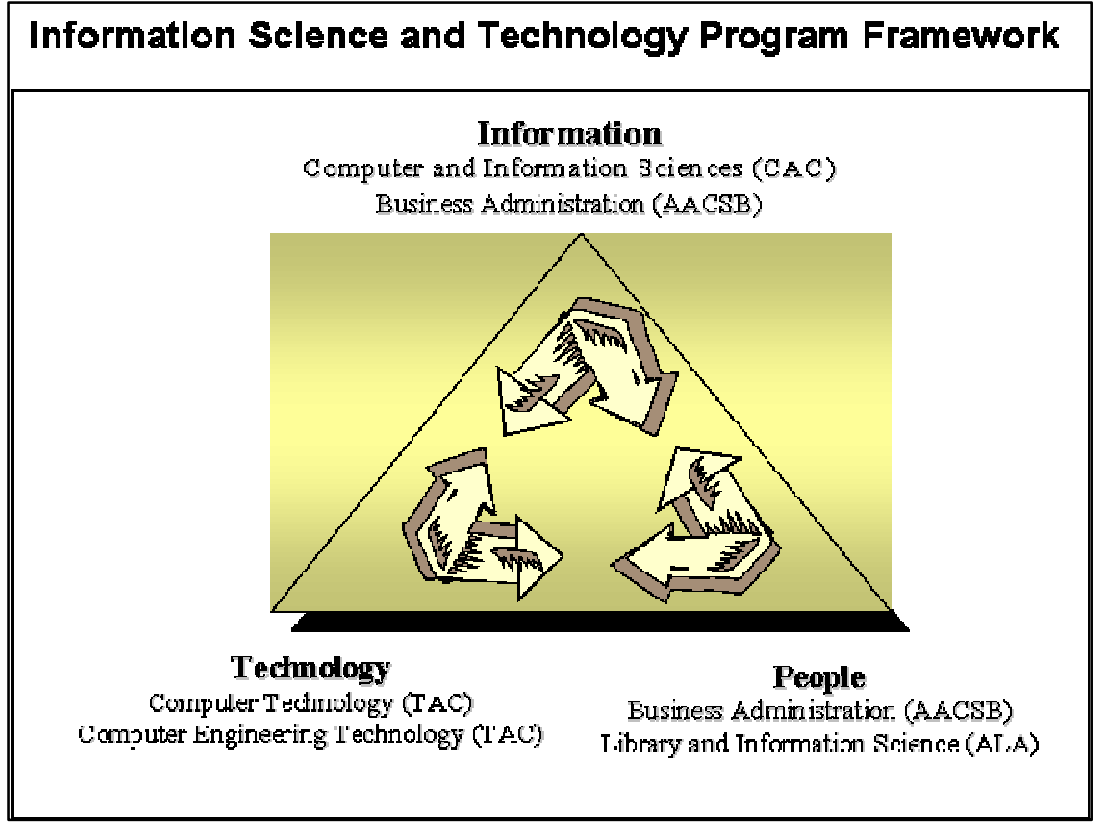

Figure 2: IST Framework and Related Accreditation Organization

Successful organizations utilize similar business structures and methods of operation; however, each may vary in the product and/or service provided to meet a specific market niche and gain a 
competitive advantage. The same holds true with academic institutions and their degree programs. In D. M. Norris and Morrison's text, Mobilizing For Transformation: How Campuses Are Preparing For The Knowledge Age, they refer to such practices as "leveraging the forces for transformation on campus" (1997, p. 1). Thus, program structures and methods of operation from similar technical degree programs were used to develop standards for the IST degree program.

This study identifies national standards for IST baccalaureate programs in the United States based on the practice of using accreditation criteria from similar disciplines as a model for program development (Burkett, 2002). Thus, the premise of this study is that accreditation criteria used for similar technical disciplines could be applied to the IST discipline with some variations.

Therefore, a survey was developed by the researcher based on common program criteria outlined in Appendix A that were gleaned from the accreditation criteria of IST-related degree programs (i.e., AACSB(2006); ALA, (2003); CAC, (2005); TAC, (2005)). The criteria for each of these programs along with the IST specific criteria were compiled into a comprehensive list. This list was transformed in a survey that was tested for validity and reliability. The resulting IST standards research survey contained 138 criteria grouped into 15 categories. Interestingly, the IST standards categories listed in the survey are similar to those used for developing organizational strategic and continuous improvement plans used by businesses ( Dolence \& D. M. Norris, 1995; D. M. Norris \& Morrison, 1997; G. Norris, Hurley, Hartley, Dunleavy, \& Balls, 2000).

The survey was sent to 50 individuals affiliated with five IST-related accrediting bodies in the United States: the Accreditation Board for Engineering and Technology (ABET) (2006); the American Library Association (ALA) (2003); American Society for Information Science and Technology (ASIS\&T) (2002); the Business Accreditation Committee (BAC) (2002); and the Computer Sciences Accreditation Board (CSAB) (2001), who served as a panel of experts in the area of IST to identify a theoretical framework for IST degree programs.

\section{Significance of Study}

The purpose of this study was to develop a set of standards with which to evaluate current and future undergraduate IST programs in the United States of America. This study's emphasis was on a theoretical framework rather than identifying specific courses.

As the IST program is relatively new and as it has evolved from several other programs, the model for the development of IST standards was based on common evaluation processes (i.e., accreditation) used by those programs from which the IST program evolved. The IST program is being considered for accreditation by ABET. These standards may be considered as potential accreditation criteria.

\section{Assumptions}

The following assumptions are made about this study:

- A sufficient number of IST experts and educators is interested in and willing to improve the quality of IST education nationwide.

- The proposed standards are adequate to measure the quality of the IST undergraduate programs nationwide.

- Participants in the study are cooperative, accurate, and honest.

\section{Limitations of the Study}

This study is limited to traditional undergraduate programs in IST in the United States of America and can only be generalized to such programs. This study does not include online or virtual IST programs, graduate IST programs, or international IST programs. 
The population of this study is relatively small as it is limited to members of the board of directors of BAC, CSAB, ASIS\&T, ALA, and ABET who felt qualified to provide an expert opinion on the IST program.

\section{Delimitation of the Study}

The emphasis of this study will be on the IST program's theoretical framework rather than identifying specific courses. Even though cognitive science degree programs are not represented in this study, the information science accreditation criteria take into account cognitive science curriculum aspects, such as human factors and human interface.

\section{Methodology}

The IST program is a relatively new degree program that does not have official program standards. Thus, the purpose of this study is to develop such standards. The IST program has been described as a multidimensional, interdisciplinary degree that integrates or merges curricula content from existing degree programs. These programs are computer and information science, library and information science, computer technology, computer engineering technology and business administration degrees. The accreditation criteria for these degree programs along with criteria from some of the initially offered IST programs were used as a basis for this study (i.e., AACSB(2006); ALA, (2003); CAC, (2005); TAC, (2005)). A few institutions that initially offered the first IST programs were Pennsylvania State University (2002), Georgia Southern University (Reichgelt, Zhang, \& Price, 2002), and Temple University (2001). These programs were reviewed and information was combined into a list of 13 categories of common criteria (see Appendix A).These criteria were transformed into a preliminary survey.

\section{Validity}

The validity of the preliminary survey was established through content validity (Gay \& Airasian, 2000; Leedy \& Ormrod, 2001; Schloss \& Smith, 1999), whereby a group of IST experts who served in various capacities (i.e., professor, dean, and administrators) in a school of information sciences and technology and who contributed to the inception of the IST program, reviewed the instrument and judged each statement on three different criteria: 1) the statement's relevance to the IST program, 2) the appropriate categorization of the statement, and 3) whether the statement measures what is intended. Respondents indicated their agreement or disagreement with each statement criteria by using a five-point Likert scale anchored by 1 (strongly disagree) and 5 (strong agreement). The content validity experts were not among the group to receive the final survey.

The validity data was evaluated based on the aggregate mean. Statements with a mean score of less than 3.0 were removed from the study as this value indicated that the respondents either disagreed with the statement's validity or had no opinion. Statements with a mean score of 3.0 to 3.5 inclusive, indicating that the respondents had no opinion about that statement, were reevaluated to determine if an anomaly existed that may warrant the retention of the statement. Statements with a mean score greater than 3.5, indicating that the respondents generally agreed with the statements, remained as they were in the survey. The survey was modified as indicated by the data analysis and uploaded to the Internet for reliability testing.

\section{Reliability}

The survey's reliability was established through the employment of a test-retest approach (Schloss \& Smith, 1999). This method consisted of selecting a sample group to complete the survey on two different occasions. In this case, the test-retest was administered to a group of 44 in- 
dividuals who were not among the group to receive the final survey. They completed the survey on the Internet within a designated time period. Two weeks later, the same individuals received a second e-mail asking them to complete the survey a second time. The scores for each individual were correlated to determine the reliability or stability of the overall survey and each survey category or subscale. The correlation coefficient for the overall survey is $r=0.84$, which is also significant at $p<0.01$. Following the completion of the test-retest procedure, results indicated that each section of the survey produced a highly significant $(p<0.01)$ correlation and combined to produce a composite survey reliability of $r(42)=.84, p=.002$. Subsequently, individual statements were further reviewed based on the reliability results and edited to produce further clarity and promote stronger reliability. The resulting IST research survey comprised of 138 criteria grouped into 15 categories.

\section{General}

The IST standards were established through the use of opinion polling whereby a panel of experts from various accrediting bodies related to IST indicated their attitude or disposition toward a proposed set of IST standards by completing a web-based survey.

Electronic surveying techniques were used as they provided an efficient and effective means of data collection (Cook, Heath, \& Thompson, 2000; Creswell, 2002; Franceschini, 2000; Shannon $\&$ Bradshaw, 2002). According to a study conducted by Shannon and Bradshaw (2002), electronic surveys received significantly quicker response rates than those delivered by mail, "with over $80 \%$ of initial responses arriving before receipt of the first returned mail survey" (p. 179). Researchers have found that respondents tended to complete electronic surveys upon receipt because they were easy to access and complete, which contributes to quick response rates (Cook, Heath, \& Thompson, 2000). Furthermore, "unlike a mail survey that can be easily mislaid, an electronic contact with a potential respondent remains in place until purposefully deleted" (Sheehan \& Hoy, 1999). The fact that the respondent may preview the file correspondence before deleting served as a reminder to complete the survey, which was viewed as a follow-up technique.

Because the members of the panel of experts were affiliated with a professional organization, and because the organization draws their members from technology-related businesses and/or universities, there was a strong indication that implementation of an electronic survey would be successful. Recent research comparing the use of postal and electronic surveys has indicated that an electronic survey will have a higher success rate when respondents are affiliated with businesses, universities or professional organizations, as they generally have e-mail accounts, access to the internet and a higher comfort level when it comes to using e-mail and the Internet (Cook, Heath, \& Thompson, 2000; Shannon \& Bradshaw, 2002).

Another benefit of using an electronic survey is the validity checking and null data entry options that were programmed into the survey. Validity checking prevented incorrect data from being entered into the survey (Freedman, 2001). In this case, only one value could be selected for each survey statement. Null data entry occurs when a form is programmed to prompt the user to answer those statements that may have been left blank, providing a higher probability of all survey statements being answered, ensuring complete survey responses. And finally, the cost of delivering an electronic survey is less than that of a postal survey, as electronic pre-notification, initial contact, survey responses, and follow-up techniques do not require postage.

To address the risk of technical problems, such as undeliverable e-mail accounts, inability to access the survey, and inability to deliver the survey response, problem-solving techniques were utilized as recommended by Shannon and Bradshaw (2002). One step was to debug the survey during pre-testing. When individuals responded to the survey during the survey pretest, any tech- 
nical difficulties encountered were caught and fixed. The other step was to send a pre-notification e-mail message prior to data collection. The pre-notification e-mail enabled the researcher to determine if the e-mail addresses were valid. If an undeliverable message was received, the correct e-mail address was obtained or the survey was sent to the participant via facsimile. These problem-solving techniques were employed for this study to reduce errors and to ensure a higher response rate since there were a limited number of experts identified for this study.

\section{Data Collection and Analysis}

The IST Standards Research Survey (available upon request) was administered to a population of 50 individuals affiliated with five IST-related accrediting bodies in the United States: ABET (2006), ALA (2003), ASIS\&T (2002), Business Accreditation Committee (BAC) (2002); and CSAB (2001), who served as a panel of experts in the area of IST to identify a theoretical framework for IST degree programs.

There were two types of statements in the survey. For the first type, the respondents were asked to indicate their level of agreement with the statement by selecting a number associated with a radio button on the electronic survey. The rating scale was as follows:

$$
\begin{aligned}
& 1=\text { Strongly Disagree } \\
& 2=\text { Disagree } \\
& 3=\text { No Opinion } \\
& 4=\text { Agree } \\
& 5=\text { Strongly Agree }
\end{aligned}
$$

The second type required the respondent to enter a number or percentage in response to a question. Only three categories contained fill-in-the-blank questions, which consisted of $9.4 \%$ (13) of the 138 statements. The survey responses were stored given a unique code and stored on a secure web server.

The data was retrieved from the web server and compared to the data received via e-mail to confirm that all data were stored in the data file. The data was cleaned by removing any duplicate or incomplete responses, resulting in 27 usable responses.

The overall mean and frequency were calculated for each statement. The mean score was used to identity the extent of agreement per statement for the overall sample set as well as for the subgroups within the sample. The frequency was used to determine the number of times each statement was rated a given score by the total sample. To determine if there was a difference in agreement across the degree groups, the means of the degree groups were compared using the Kruskal-Wallis test (Kinnear \& Gray, 2004).

\section{Results}

The research survey comprised of 15 categories containing 138 questions representing accreditation criteria for the IST degree program. The survey was sent to 50 participants, of which 27 usable responses were returned via e-mail and stored on a web server for a return rate of $54 \%$.

\section{Respondent Demographics}

The 27 respondents had 10 different titles, worked in 25 departments at 20 universities, 2 technical schools, 2 public libraries, 1 insurance company, and 1 technical innovation organization, possessed a master's or doctoral degree in 20 disciplines, taught courses in 17 curriculum areas or held administrative positions, and held positions in one of the 5 accreditation organizations. 
Responses to faculty rank or job title revealed that a majority of the respondents, $40.7 \%(n=11)$, held the rank of dean or dean/professor; that one-third held the rank of professor, professor/chair or professor/director, $33.3 \%(n=9)$; that $11.1 \%(n=3)$ were directors; and that the remaining $14.8 \%(n=4)$ respondents held management or administrative positions.

Responses to highest degree earned revealed that a majority of the respondents, $74.1 \%(n=20)$, held a doctoral degree and the remaining had a master's degree.

Responses to the academic discipline of highest degree earned showed that exact names of the discipline varied with the exception of computer science, library science, and management, who received two responses. The rest received one response. The results indicated that both business management and computer science degrees were held by $25.9 \%(n=7)$ of the respondents and $22.2 \%(n=6)$ held degrees in mathematics.

\section{Results by Highest Degree Earned}

A Kruskal-Wallis test was conducted to determine if the survey results varied as a result of the respondent's highest degree earned (i.e., doctorate and master's). The Kruskal-Wallis test revealed no significant difference between the respondents' highest degrees earned and the mean score for each category. However, there were two statements that showed a significant difference between degree groups:

- Faculty can have specialized industry experience in the field of primary teaching responsibilities but no doctoral degree. The chi-squared approximation to the Kruskal-Wallis test is significant: $x^{2}(1)=5.639 ; p<.018$.

- Applied scholarship should pertain to the application transfer, and interpretation of knowledge to improve IST practices. The chi-squared approximation to the KruskalWallis test is significant: $x^{2}(1)=5.527 ; p<.019$.

\section{Results by Participant}

The responses to the statements in the IST Standards Survey revealed that $100 \%(n=27)$ of the respondents' overall mean scores (the mean across their answers to all 15 categories) ranged from 4.0 (agree) to 5.0 (strongly agree), indicating that, on average, $92.6 \%(n=25)$ of the participants agreed and $7.4 \%(n=2)$ strongly agreed with the IST standards.

\section{Results by IST Category: Likert Scale}

The mean scores for the Likert statements per category were calculated to determine the level of agreement per category. The mean score for the IST standards categories ranged from 4.7 to 3.7 (see Table 2). These ratings indicated that the respondents agreed with all but one categoryfaculty qualifications - which received a score of 3.7 (near agree). Furthermore, the mean score for each category's criterion indicated a high level of agreement for the categorical criteria. The minimum mean score for each category's criteria is also listed in the right hand column of Table 2 . 
Table 2: IST Program Standards Categorical Mean Scores

\begin{tabular}{lll}
\hline Category & Mean & $\begin{array}{l}\text { Minimum } \\
\text { Mean Score }\end{array}$ \\
\hline Faculty Size Composition, and Deployment & 4.7 & 4.4 \\
Faculty Instructional Responsibilities & 4.7 & 4.5 \\
Curriculum Planning and Evaluation & 4.7 & 4.6 \\
Student Support & 4.7 & 4.6 \\
Mission Statement & 4.7 & 4.5 \\
Institutional Support and Financial Resources & 4.6 & 4.2 \\
Student Selection & 4.6 & 4.1 \\
Program Assessment & 4.6 & 4.5 \\
Instructional Resources & 4.6 & 4.5 \\
Intellectual Contributions & 4.6 & 4.2 \\
Program Objectives & 4.5 & 4.2 \\
Curriculum Content and Evaluation & 4.4 & 4.4 \\
Faculty Development, Promotion, Retention, and Renewal & 4.4 & 4.1 \\
Faculty Recruitment, Selection, and Orientation & 4.3 & 4.1 \\
Faculty Qualifications & 3.7 & 3.2 \\
\hline
\end{tabular}

Note. $N=27$. Scale: $1=$ Strongly Disagree to $5=$ Strongly Agree

\section{Results by IST Category: Fill-in-the-blank}

Participants were asked to provide a number or percentage in response to a fill-in-the-blank question. The responses to these questions are listed in Table 3.

Table 3: Results by IST Category: Fill-in-the-blank

\begin{tabular}{lcccc}
\hline \multirow{2}{*}{ Criteria } & Mean & \multicolumn{3}{c}{ Percentiles } \\
\cline { 2 - 5 } & & 25 & 50 & 75 \\
\hline
\end{tabular}

Faculty Size, Composition, and Deployment

$\begin{array}{llll}\text { The minimum percent of student credit hours that } \quad 66.0 \% & 60.0 \% & 66.0 \% & 75.0 \%\end{array}$ should be taught by full-time faculty.

The minimum percent of credit hours that should be $\quad 66.0 \% \quad 60.0 \% \quad 70.0 \% \quad 75.0 \%$ taught by full-time faculty in the day program.

The minimum percent of credit hours that should be $\quad 57.3 \% \quad 50.0 \% \quad 60.0 \% \quad 75.0 \%$ taught by full-time faculty in the evening program.

$\begin{array}{lllll}\text { The number of credit hours, per term, that should be } & 9.0 & 9.0 & 9.0 & 9.0\end{array}$ the normal teaching load for faculty. 
Table 3: Results by IST Category: Fill-in-the-blank

\begin{tabular}{|c|c|c|c|c|}
\hline \multirow[t]{2}{*}{ Criteria } & \multirow[t]{2}{*}{ Mean } & \multicolumn{3}{|c|}{ Percentiles } \\
\hline & & 25 & 50 & 75 \\
\hline $\begin{array}{l}\text { The number that should be the credit hour reduction } \\
\text { for faculty who are working on intellectual contribu- } \\
\text { tions in the form of a published manuscript. }\end{array}$ & 3.30 & 3.0 & 3.0 & 3.0 \\
\hline \multicolumn{5}{|l|}{ Faculty Qualifications } \\
\hline $\begin{array}{l}\text { The percent that must constitute the total number of } \\
\text { full-time equivalent faculty. }\end{array}$ & $74.1 \%$ & $60.0 \%$ & $80.0 \%$ & $90.0 \%$ \\
\hline $\begin{array}{l}\text { The percent that should not be exceeded in terms of the } \\
\text { total full-time equivalent faculty who are academically } \\
\text { qualified but who do not possess doctoral degrees. }\end{array}$ & $23.6 \%$ & $10.0 \%$ & $20.0 \%$ & $25.0 \%$ \\
\hline \multicolumn{5}{|l|}{ Curriculum Content and Evaluation } \\
\hline $\begin{array}{l}\text { The minimum number that should be the total semester } \\
\text { hour credits for the baccalaureate of Information Sci- } \\
\text { ences and Technology degree. }\end{array}$ & 117.4 & 120.0 & 120.0 & 126.5 \\
\hline $\begin{array}{l}\text { The minimum number of semester hours of study in } \\
\text { humanities, social sciences, arts and other disciplines } \\
\text { that serve to broaden the background of the student that } \\
\text { must be included in the curriculum. }\end{array}$ & 43.3 & 30.0 & 37.0 & 60.0 \\
\hline $\begin{array}{l}\text { The minimum number of semester hours of study in the } \\
\text { major of information sciences and technology that must } \\
\text { be included in the curriculum. }\end{array}$ & 38.3 & 24.0 & 40.0 & 46.0 \\
\hline $\begin{array}{l}\text { The minimum number of semester hours of quantitative } \\
\text { studies that must be included in the curriculum. }\end{array}$ & 14.5 & 9.0 & 12.0 & 18.0 \\
\hline $\begin{array}{l}\text { The minimum number of semester hours of science that } \\
\text { must be included in the curriculum. }\end{array}$ & 10.0 & 7.5 & 9.0 & 12.8 \\
\hline $\begin{array}{l}\text { The percent of credit hours for the IST degree that } \\
\text { should be earned at the degree-awarding institution. }\end{array}$ & $47.9 \%$ & $30.0 \%$ & $50.0 \%$ & $64.5 \%$ \\
\hline
\end{tabular}

Note. $N=27$.

\section{Analysis of Results}

\section{Participants}

The mean score of each participant's Likert scale responses indicated that all participants agreed with the IST standards overall. Furthermore, there was no significant difference between the responses of those who possessed a doctoral degree versus a master's degree. However, two criteria did show a significant difference in response between degree groups: 1) faculty can have specialized industry experience in the field of primary teaching responsibilities but no doctoral degree and 2) applied scholarship should pertain to the application transfer, and interpretation of knowledge to improve IST practices. The mean score for the first criteria indicated that the doctoral group did not agree with this criterion as strongly as the master's group and the mean score for the second criterion indicated that the master's group did not agree with this criterion as strongly as the doctoral group. 
The general and scholarly orientation of the academic institution with which the respondent was affiliated may have impacted these two criteria. In other word, the faculty qualifications and research requirements differ from an institution that emphasizes teaching versus one that emphasizes intellectual contributions; thus, their opinions would vary depending on their institutional affiliation.

\section{IST Standards Categorical Criteria}

A complete list of IST Standards is provided in Appendix B. The list contains 124 criteria. In some cases several criteria were combined into one succinct statement, which reduced the list from 138 to 124. For example, the criteria "The mission statement must be appropriate to higher education and be consistent with the mission of the parent institution" appeared as three statements on the survey. One statement to determine if a mission statement was necessary, another to determine if the mission statement should be appropriate to higher education, and lastly, one to determine if the mission statement should be consistent with the parent institution.

Many of the IST program criteria were obvious and could apply to any degree program. However, several categories contained IST defining criteria and are discussed within that category.

\section{Mission statement $[M=4.7]$}

The mission statement of an academic program is extremely important for maintaining focus, setting objectives, and evaluating progress.

\section{Program objectives [ $M=4.5]$}

Clear and specific program objectives are a necessity to achieve the program's mission, to track progress, and maintain quality control.

\section{Program assessment $[M=4.6]$}

Assessment is the means by which an organization may determine if their objectives are being met. This supports the respondents' high level of agreement for the program assessment category. One respondent felt that some of these criteria were obvious. This may be true, but sometimes the obvious are the first to be overlooked or taken for granted, which may be why most of the accrediting bodies, from which the IST survey criteria were gleaned, included them in their accreditation guidelines.

\section{Faculty recruitment, selection and orientation $[M=4.4]$}

In order to have a successful program, there must be a process through which to obtain the necessary human resources. The participants of this study agreed that recruiting and selecting faculty were important, but did not feel as strongly about the orientation process. The accreditation organizations that include these criteria understand the need to acclimate individuals to the organization as this is the first step in the retention process.

\section{Faculty development, promotion, retention, and renewal $[M=4.4]$}

It is very important to develop, promote, retain and renew faculty. It is costly, both financially and intellectually, to continually replace employees. Therefore, the establishment of practices to develop, promote and retain faculty is a must in the IST program. As technology changes, faculty will need to maintain technical currency. Furthermore, it is just as important to have a process by which to fill positions that become available through normal attrition activities. 


\section{Faculty size, composition, and deployment $[M=4.7]$}

It is important to have an academic plan that outlines how many employees are needed, what their roles and responsibilities should be, and where they will be most effective in order to achieve the organizational objectives.

Depending on the focus and objectives of the academic program, each organization will have criteria specific to its mission. This holds true for faculty size, composition and deployment. The respondents suggested the following faculty composition for the IST program (see Table 3 for the percentiles from which these values came):

- A majority of the respondents agreed that the minimum percent of the student credit hours that should be taught by full-time faculty ought to be $60 \%$ to $75 \%$.

- A majority of the respondents agreed that the minimum percent of the credit hours that should be taught by full-time faculty in the day program ought to be $60 \%$ to $75 \%$.

- A majority of the respondents agreed that the minimum percent of the student credit hours that should be taught by full-time faculty in the evening program ought to be $50 \%$ to $75 \%$.

- A majority of the respondents agreed that the number of credit hours, per term, that should be the normal teaching load for faculty ought to be 9 credits.

- A majority of the respondents agreed that the number of credit hour reduction for faculty who were working on intellectual contributions in the form of a published manuscript ought to be 3 credits.

Note: The ranges allow for the variation in institutional focus (e.g. teaching, research, service).

Two additional criteria were suggested by respondents:

- In the above, the teaching load should be 9 hours if teaching a graduate course and/or publishing.

- Reduced loads are generally required.

These items, though not included in the survey and not rated by the respondents, explain the 9 credit teaching load and could be used in future studies.

\section{Faculty qualifications $(M=3.7)$}

The employee qualifications for academic programs may vary. In this case the participants agreed, but not as strongly as in the other categories. The mean score for the faculty qualifications category is not enough to indicate that the respondents agreed with the criteria. Each of the seven statements in this category received different levels of agreement. The respondents did not agree that: (a) faculty should hold a masters degree, have industry experience, and be enrolled in a doctoral program in the area in which the individual teaches, (b) faculty can have specialized course work in the field of primary teaching responsibilities but no doctoral degree, or (c) faculty can have specialized industry experience in the field of primary teaching but no doctoral degree.

Seventy-five percent of the respondents agreed that faculty should have sufficient academic and professional qualifications to accomplish the program's objectives, and that faculty should hold a doctoral degree in the area in which the individual teaches or may hold a doctoral degree outside the area as long has they have industry experience or receive supplemental preparation.

In response to the fill-in-the-blank statements in the faculty qualifications category, the respondents indicated that: (a) $60 \%$ to $90 \%$ of the faculty must constitute the total number of full-time 
equivalent, and (b) $10 \%$ to $25 \%$ should be the maximum total of full-time faculty equivalent that are academically qualified but do not possess a doctoral degree.

The response to the fill-in-the-blank questions suggest that, even though the respondents could not agree on the qualifications of faculty who did not possess a doctoral degree, faculty with such qualifications may make up approximately one fourth (23.6\%) of the faculty full-time equivalent.

\section{Institutional support and financial resources $[M=4.6]$}

Budget and academic resources are key to any organization as is evident by the respondents' strong agreement.

Note: It was not clear, however, whether the funds should be provided by the institution or the school or college that houses the IST program.

\section{Curriculum content and evaluation $[M=4.3]$}

Curriculum is the major defining factor for the IST program. The respondents defined the curriculum as follows:

- 120 to 127 credit hours should be the minimum number of total semester hour credits for the IST degree;

- the minimum number of total semester hours of study in the major of information sciences and technology should be 24 to 46 credit hours;

- the minimum number of total semester hours of study in the humanities, social sciences, arts and other disciplines that serve to broaden the background of the student should be 30 to 60 credit hours;

- the minimum number of total semester hours of quantitative study should be 9 to 18 credit hours;

- the minimum number of total semester hours of science should be 8 to 13 credit hours; and

- the minimum number of total credit hours that should be earned as the degree-awarding institution should be $30 \%$ to $65 \%$.

The ranges given in these areas enable institutions to choice the figures that work best for their specific needs.

Other requirements may be added as emerging information technologies are developed and incorporated into the IST program. Furthermore, this study may not include all curriculum requirements. As with all IT programs, the IST program is in its infancy and still evolving as technology and business needs change (Association for Computing Machinery, 2005).

This study identified minimum IST program requirements. It did not identify specific required core courses, as the intent was for a theoretical framework. However, based on the Computing Curricula: Information Technology Volume (2005, p. 32) the core would contain courses pertaining to the following topics: IT Fundamentals, networking, web systems, information management, human-computer interaction, system administration, system integration and architecture, and integrative programming, information assurance and security, the social and professional issues of IT, an integrative capstone experience.

Several institutions currently offering IST programs require the following core courses: 
- information, people, and technology, seminar in information sciences and technology, organization of data, networking and telecommunications, new media and the web, introduction to systems development and design (Pennsylvania State University, 2005).

- introduction to information technology, introduction to information systems, information evaluation, organization and use, foundations of software, human-computer interaction I, systems analysis I, database management systems, social aspects of information systems, server technology infrastructure, information technology services, software project management, design problem I, and design problem II (Drexel University, 2005).

- computational foundations, computer networks I, social issues in information technology, professional issues in information technology, systems analysis and design, and computer information technology project (Vermont Technical College, 2005).

- principles of information technology, principles of computer science I, principles of computer science II, web development I, introduction to information technology, decision support systems, and information systems senior capstone (Radford University, 2002).

- programming concepts I, programming concepts II, data structures, operating systems concepts, and computer networks (Chadron State College, 2001).

These institutions offered different courses for their IST programs. Identifying IST core course could be the subject of future studies.

\section{Curriculum planning and evaluation $[M=4.7]$}

It is difficult know where the program is going without a curriculum plan, and even more difficult to know if the curriculum is effective without an evaluation process. The evaluation criteria will be necessary for continuous improvement of the IST curriculum. The respondents strongly agreed with these criteria. One individual emphasized the need for "on-going and continuous element of the curriculum planning process should be stressed."

\section{Instructional resources $[M=4.5]$}

Again, while this category may seem obvious, it needs to be stated. Faculty cannot be effective without the necessary instructional resources. The availability of the necessary instructional resources provides access to appropriate technology and related resources are imperative to success of the IST program

\section{Faculty instructional responsibilities $[M=4.5]$}

One of the respondents eloquently stated the need for faculty instructional responsibilities in the IST programs by indicating that "oversight and assurance of faculty and engagement in the classroom is an important element of administrative accountability." The respondents strongly agreed that faculty need to be effective, available, and innovative, and that they should maintain currency in their instructional field.

\section{Intellectual contributions $[M=4.6]$}

To remain competitive in this fast-growing field, faculty will need to contribute to the IST program through instructional developments and applied scholarship. Intellectual contributions may vary, but all respondents agreed it is necessary. 


\section{Student selection $[M=4.6]$}

Like any business, clients or consumers are important to the IST program. There needs to be a systematic process for student selection and retention.

Note: one participant strongly cautioned against exceptions by stating that "waiving admission standards or academic prerequisites should be granted infrequently." In doing so, the institution may reduce the quality of the program and affect the student's ability to succeed.

\section{Student support ( $M=4.7$ )}

Students are an integral part of the IST program and critical to its success, which is why student support is so important. Without the students, the IST program would not be necessary.

\section{Summary}

There are no lines of demarcation, in terms of categories that delineate the IST program from any other; however, the criteria or statements within the categories are what differentiate the program.

Several categories were considered generic and would apply to any degree program, whereas others contained more defining factors specific to the IST program. The defining categories were program objectives; faculty size, composition, and deployment; faculty qualifications; institutional support and financial resources; curriculum content and evaluation; instructional resources; and intellectual contributions.

\section{Future Research}

There are several areas in which future research may be conducted. First, during the review, evaluation and revision process, additional criteria were identified. These criteria, along with those offered during this study, will need to be tested and evaluated. Second, standards criteria will need to be developed for IST continuing education and distance learning programs. Third, current IST programs may be evaluated based on these criteria. Fourth, the result of this study may be compared to the data collected from a university that offers the IST program. Finally, similar standards will need to be developed for online, continuing education, graduate and international IST programs.

\section{Conclusion}

The use of these standards will enable academic institutions to plan, develop, implement, evaluate, and improve IST programs. The academic program's mission statement standards are extremely important for maintaining focus, setting objectives, and evaluating progress. Clear and specific program objectives are a necessity to achieve the program's mission. Assessment is the means by which an organization may determine if their objectives are being met. In order to have a successful program, there must be a process through which to obtain the necessary human resources.

The standards outlined in the faculty recruitment, selection and orientation category, the faculty development, promotion, retention, and renewal category, the faculty size, composition, and deployment category, and the faculty qualifications category are essential for developing human resource processes and policies. Budget and academic resources are key to the success of any organization. The institutional support and financial resources standards ensure the necessary funds and resources are available for the program.

Curriculum is the major defining factor for the IST program. The standards define the curriculum as follows: (a) a minimum of 120 to 127 total semester hour credits for the degree, (b) a minimum 
of 24 to 46 total semester hour credits of IST curriculum, (c) a minimum of 30 to 60 total semester hours of study in the humanities, social sciences, arts, and other disciplines that serve to broaden the background of the student, (d) a minimum of 9 to 18 semester hours of quantitative study, (e) a minimum of 8 to 13 credit hours of science, and (f) a minimum of $30 \%$ to $65 \%$ percent of the credit hours should be earned at the degree-awarding institution. The curriculum planning and evaluation standards ensure the program is on track and guarantees continue improvement.

The instructional resources standards provide assurance of learning. Clearly defined faculty instructional responsibilities provide administration with the insurance that the faculty are effective, available, innovative, engaged in the classroom, and current in their instructional field. The intellectual contributions standards require continued faculty contribution to the IST program through instructional developments and applied scholarship.

Like any business, clients or customers are important to the IST program. The student selections standards provide a systematic process for student selection and retention. As students are an integral part of the IST program and critical to its success, the student supports standards help the institution support and retain students.

Any academic organization interested in developing, implementing, evaluating, or improving their IST degree program would benefit from following the standards outlined in this study. These standards will withstand technological advances as they are based on specific objectives with measurable outcomes as designated by the institution. The standards encourage the institution to evaluate and document the outcomes to determine if improvements are required. If the mission of the program changes in reaction to economic, technological, or global influences, using the criteria as a checklist for change management will help the institution achieve the new goals and objectives.

\section{References}

Association to Advance Collegiate Schools of Business (AACSB). (2002). 2002-2003 Business Accreditation Committee (BAC). Retrieved Jun 8, 2002, from http://www.aacsb.edu/accreditation/business/bacroster.asp

Association to Advance Collegiate Schools of Business (AACSB International. (2006). Eligibility procedures and standards for business accreditation. Retrieved May 2, 2006, from http://www.aacsb.edu/accreditation/business/STANDARDS.pdf

Accreditation Board for Engineering and Technology (ABET). (2006). Accredited engineering technology programs. Retrieved May 5, 2006, from http://www.abet.org/accredittac.asp

American Library Association (ALA). (2002). ALA Committee on Accreditation/Office for Accreditation. Retrieved Jun 8, 2002, from http://www.ala.org/alaorg/oa/roster.html

American Library Association (ALA). (2003). Accreditation process policies \& procedures. Retrieved Jun 8, 2006, from http://www.ala.org/ala/accreditation/accredstandards/ap3.htm

American Society for Information Science and Technology (ASIS\&T). (2002). 2002 BOARD OF DIRECTORS. Retrieved Jun 8, 2002, from http://www.asis.org/Board/board.html

Association for Computing Machinery. (2005). Computing curricula: Information technology volume. Retrieved March 10, 2006, from http://stemrc.aihec.org/computers/BPC2/Shared\%20Documents/ITCurriculum_October_2005.pdf

Burkett, W. (2002). Constructing a workable computer information science/computer science curriculum: A template for developing a cross-discipline model. Journal of Information Technology Education, 1(1), 65-75. Available at http://jite.org/documents/Vol1/v1n1p065-076.pdf 
Computing Accreditation Commission (CAC). (2005, November 1, 2004). Criteria for accrediting computing programs. Retrieved June 19, 2005, from http://www.abet.org/forms.shtml

Chadron State College. (2001). Degree of Bachelor of Science with a Major in Information Science and Technology (2001-2005). Retrieved May 5, 2006, from http://www.csc.edu/mathsci/ist/degree.htm

Commission of Professionals in Science and Technology. (2003). The outlook in 2003 for information technology workers in the USA. Washington, D.C.: CPST.

Cook, C., Heath, F., \& Thompson, R. (2000). A meta-analysis of response rates in Web- or Internet-Based surveys. Educational and Psychological Measurement, 60(6), 821-836.

Creswell, J. W. (2002). Educational research: planning, conducting, and evaluating quantitative and qualitative research. Upper Saddle River, N.J.: Merrill.

CSAB. (2001, April 19, 2002). CSAB Board of Directors. Retrieved May 22, 2002, from http://www.csab.org/CSAB board.html

Dolence, M. G., \& Norris, D. M. (1995). Transforming higher education: A vision for learning in the 21st century. Ann Arbor, Mich.: Society for College and University Planning.

Drexel University. (2005). College of Information Science and Technology: Undergraduate Checklist. Retrieved May 5, 2006, from http://www.cis.drexel.edu/forms/2005\%20updated\%20BSIT\%20curriculum.pdf

Franceschini, L. A., III. (2000, November 17, 2000). Navigating electronic survey methods: Three pilot studies. Paper presented at the Annual Meeting of the Mid-South Educational Research Association, Bowling Green, KY.

Freedman, A. (2001). Computer desktop encyclopedia. New York: Amacom.

Gay, L. R., \& Airasian, P. W. (2000). Educational research: Competencies for analysis and application (6th ed.). Upper Saddle River, N.J.: Merrill.

Kinnear, P. R., \& Gray, C. D. (2004). SPSS 12 made simple (1st ed.). Hove, East Sussex ; New York: Psychology Press.

Leedy, P. D., \& Ormrod, J. E. (2001). Practical research: Planning and design (7th ed.). Upper Saddle River, N.J.: Merrill Prentice Hall.

Nathan, B., \& Turvey, J. (2001). Skills competencies needed by Arizona's workforce: The software and information technology industry. Phoenix, AZ: Advancing Employee Systems, Inc.

Norris, D. M. \& Morrison, J. L. (1997). Mobilizing for transformation: How campuses are preparing for the knowledge age. San Francisco: Jossey-Bass Publishers.

Norris, G., Hurley, J. R., Hartley, K. M., Dunleavy, J. R., \& Balls. J. D. (2000). E-business and ERP: Transforming the enterprise. New York: John Wiley.

Pennsylvania State University. (2002). School of Information Sciences and Technology Strategic Plan, Fiscal Year 2002-2003 through 2004-2005. State College, PA: The Pennsylvania State University.

Pennsylvania State University. (2005). Information Sciences and Technology. Retrieved May 5, 2006, from htt:/www.psu.edu/bulletins/bluebook/major/ist.htm

Radford University. (2002). B.S. in Information Science and Systems. Retrieved May 5, 2006, from http://www.radford.edu/ cist/AcadAdvise/October\%202002/ISASOverview\%200203.htm

Reichgelt, H., Zhang, A., \& Price, B. (2002). Designing an information technology curriculum: The Georgia Southern University experience. Journal of Information Technology Education, 1(4), 213-221. Available at http://jite.org/documents/Vol1/v1n4p213-221.pdf

Schloss, P. J., \& Smith, M. A. (1999). Conducting research. Upper Saddle River, NJ: Merrill.

Schneider, G. (2006). Electronic commerce: Sixth annual edition. Canada: Thomson: Course Technology. 
Shannon, D. M., \& Bradshaw, C. C. (2002). A comparison of response rate, response time, and costs of mail and electronic surveys. The Journal of Experimental Education, 70(2), 179-192.

Sheehan, K. B., \& Hoy, M. G. (1999). Using e-mail to survey internet users in the United States: Methodology and assessment. Journal of Computer-Mediated Communication, 4(3).

Technology Accreditation Commission (TAC). (2005). Criteria for accrediting engineering technology programs. Retrieved May 2, 2006, from http://www.abet.org/Linked\%20DocumentsUPDATE/Criteria\%20and\%20PP/T001\%2005-06\%20TAC\%20Criteria\%209-15-05.pdf

Temple University. (2001). IS\&T @ Temple University: Information Science \& Technology. Retrieved July 18, 2002, from http://ww2.cis.temple.edu/ist/

United States Department of Labor Bureau of Labor Statistics. (2005). Occupational employment projections to 2014. Monthly Labor Review Online, 128(11), 70-101.

Vermont Technical College. (2005). B.S. of Computer Information Technology. Retrieved May 5, 2006, from http://catalog.vtc.edu/preview_program.php?catoid $=10 \&$ poid $=298$

\section{Appendix A}

\section{IST Program Accreditation Criteria Common Categories}

Thirteen categories emerged during the compilation of the accreditation criteria from the five accrediting bodies used in this study and the IST criteria. These criteria were used to develop the validity survey for this study. The validity survey is available upon request.

\begin{tabular}{|c|c|c|c|c|c|c|c|}
\hline \multirow{3}{*}{ No. } & \multirow{3}{*}{ Category } & \multicolumn{6}{|c|}{ Accrediting Body } \\
\hline & & & & CAC & CAC & & \\
\hline & & IST & AACSB & IS & $\mathrm{CP}$ & ALA & TAC \\
\hline 1 & Administration & & & & & $\mathrm{X}$ & $\mathrm{X}$ \\
\hline \multirow[t]{18}{*}{2} & Curriculum Content and Requirements & $\mathrm{X}$ & $\mathrm{X}$ & $\mathrm{X}$ & & $\mathrm{X}$ & $\mathrm{X}$ \\
\hline & Computer Competency & & & & & & $\mathrm{X}$ \\
\hline & Computer Science & $\mathrm{X}$ & & & $\mathrm{X}$ & & \\
\hline & Cooperative Education Experience & & & & & & $\mathrm{X}$ \\
\hline & General & & & $\mathrm{X}$ & $\mathrm{X}$ & & \\
\hline & Quantitative Analysis & $\mathrm{X}$ & & $\mathrm{X}$ & $\mathrm{X}$ & & $\mathrm{X}$ \\
\hline & Humanities & $\mathrm{X}$ & & & & & $\mathrm{X}$ \\
\hline & Information Systems & $\mathrm{X}$ & & $\mathrm{X}$ & & & \\
\hline & Information Systems Environment & & & $\mathrm{X}$ & & & \\
\hline & Sciences & $\mathrm{X}$ & & & $\mathrm{X}$ & & $\mathrm{X}$ \\
\hline & Social Sciences & $\mathrm{X}$ & & & & & $\mathrm{X}$ \\
\hline & Technical Skills and Techniques & $\mathrm{X}$ & $\mathrm{X}$ & $\mathrm{X}$ & $\mathrm{X}$ & $\mathrm{X}$ & $\mathrm{X}$ \\
\hline & Technical Currency & $\mathrm{X}$ & $\mathrm{X}$ & $\mathrm{X}$ & $\mathrm{X}$ & & $\mathrm{X}$ \\
\hline & Technical Design & & & & & & $\mathrm{X}$ \\
\hline & Technical Electives & $\mathrm{X}$ & $\mathrm{X}$ & $\mathrm{X}$ & $\mathrm{X}$ & $\mathrm{X}$ & $\mathrm{X}$ \\
\hline & Technical Sciences & & & & & & $\mathrm{X}$ \\
\hline & Technical Specialties & $\mathrm{X}$ & $\mathrm{X}$ & $\mathrm{X}$ & $\mathrm{X}$ & $\mathrm{X}$ & $\mathrm{X}$ \\
\hline & Additional Areas of Study & $\mathrm{X}$ & & $\mathrm{X}$ & $\mathrm{X}$ & & \\
\hline 3 & Curriculum Evaluation & $\mathrm{X}$ & $\mathrm{X}$ & & & & \\
\hline 4 & Curriculum Planning & $\mathrm{X}$ & $\mathrm{X}$ & & & & \\
\hline \multirow[t]{7}{*}{5} & Faculty & & $\mathrm{X}$ & $\mathrm{X}$ & $\mathrm{X}$ & $\mathrm{X}$ & $\mathrm{X}$ \\
\hline & Qualifications & $\mathrm{X}$ & $\mathrm{X}$ & & & & \\
\hline & Recruitment, Selection and Orientation & $\mathrm{X}$ & $\mathrm{X}$ & & & & \\
\hline & $\begin{array}{l}\text { Development, Promotion, Retention, and Re- } \\
\text { newal }\end{array}$ & $X$ & $X$ & & & & \\
\hline & Size, Composition, and Deployment & $\mathrm{X}$ & $\mathrm{X}$ & $\mathrm{X}$ & $\mathrm{X}$ & & $\mathrm{X}$ \\
\hline & Instructional Responsibilities & $\mathrm{X}$ & $\mathrm{X}$ & & & & \\
\hline & Intellectual Contributions & $\mathrm{X}$ & $\mathrm{X}$ & & & & \\
\hline
\end{tabular}




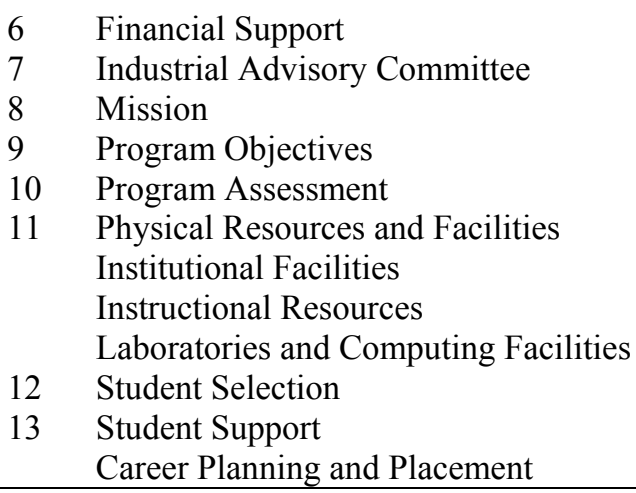

$\begin{array}{llllll}\mathrm{X} & & \mathrm{X} & \mathrm{X} & \mathrm{X} & \mathrm{X} \\ \mathrm{X} & & & & \mathrm{X} & \\ \mathrm{X} & \mathrm{X} & \mathrm{X} & & \mathrm{X} & \\ \mathrm{X} & \mathrm{X} & \mathrm{X} & \mathrm{X} & \mathrm{X} & \\ \mathrm{X} & & & & \mathrm{X} & \mathrm{X} \\ \mathrm{X} & & \mathrm{X} & \mathrm{X} & & \\ & \mathrm{X} & & & & \\ & \mathrm{X} & \mathrm{X} & \mathrm{X} & \mathrm{X} & \mathrm{X} \\ \mathrm{X} & \mathrm{X} & \mathrm{X} & & \mathrm{X} \\ \mathrm{X} & \mathrm{X} & \mathrm{X} & & & \end{array}$

\section{Appendix B IST Standards Categorical Criteria}

The following is an outline of the categorical criteria that resulted from this study. Some of the criteria may be familiar and may apply to any program regardless of the discipline.

\section{Mission Statement}

- The program must have a clear mission statement.

- The mission statement must be appropriate to higher education and be consistent with the mission of the parent institution.

- The program mission statement must be published, periodically reviewed, and revised as needed.

\section{Program Objectives}

- The educational objectives of the program must be clearly specified.

- The characteristics of students must be identified.

- The emphasis on teaching, intellectual contributions (research), service and high quality education must be clearly specified.

- Programs must demonstrate implementation of continuous improvement processes and procedures for the program.

- The program content should provide an integrated educational experience directed toward development of the ability to apply pertinent knowledge to the solution of practical problems in the graduate's information sciences and technology specialty.

- The program's technical currency is important and must be assured by such means of an active industrial advisory committee.

\section{Program Assessment}

- The program must have documented and measurable outcomes.

- The program's objectives must include expected outcomes for graduating students.

- The extent to which each program objective is being met must be periodically assessed.

- The results of the program's periodic assessments must be used to help identify opportunities for program improvement.

- The results of the program's assessments and the actions taken based on the results must be documented.

\section{Faculty Recruitment, Selection, and Orientation}

- Faculty recruitment practices must be clearly defined and should be consistent with the program's mission.

- Faculty selection practices must be clearly outlined and should be consistent with the program's mission.

- Faculty orientation practices should be consistent with the program's mission. 
- The program should demonstrate continuous efforts to achieve demographic diversity in its faculty by recruiting faculty from multicultural, multiethnic, and multilingual backgrounds.

Faculty Development, Promotion, Retention, and Renewal

- A process should be developed to determine appropriate teaching assignments and service workloads.

- A process should be developed to guide and mentor faculty.

- A process should be developed to provide adequate support for activities that implement the program's mission.

- A formal, periodic review process should exist for reappointment, promotion, and tenure decisions. Effective teaching, course development, instructional innovations, and service should be taken into consideration as part of these decision processes.

- Advising duties must be a recognized part of faculty members' workloads.

- There should be clearly defined policies for adjunct faculty.

Faculty Size, Composition, and Deployment

- The school/college should have sufficient faculty capable of accomplishing program objectives.

- There should be sufficient full-time faculty to provide stability for the program.

- Part-time faculty, when appointed, should balance and complement the teaching competencies of the full-time faculty.

- Particularly in the teaching of specialties that are not represented in the expertise of the full-time faculty, part-time faculty should enrich the quality and diversity of a program.

- Sixty to seventy-five percent of the overall student credit hours should be taught by fulltime faculty.

- Sixty to seventy-five percent of the day program credit hours should be taught by fulltime faculty.

- Fifty to seventy-five percent off evening program credit should be taught by full-time faculty.

- The normal teaching load for faculty, per term, should be 9 per academic year.

- A 3 credit hour reduction will be given to faculty who are working on intellectual contributions in the form of a public manuscript.

Faculty Qualifications (in order of preference / importance)

- Faculty should have sufficient academic and professional qualifications to accomplish the program's mission.

- Faculty should hold a doctoral degree in the area in which the individual teaches.

- Faculty can hold a doctoral degree outside the area in which the individual teaches as long has they have industry experience in the area in which the individual teaches.

- Faculty can hold a doctoral degree outside the area in which the individual teaches as long has the individual receives supplement preparation in the form of professional development.

- Faculty can have specialized industry experience in the field of primary teaching responsibilities but no doctoral degree.

- Faculty can have specialized coursework in the field of primary teaching responsibilities but no doctoral degree.

- Faculty should hold a masters degree, have industry experience, and be enrolled in a doctoral program in the area in which the individual teaches.

- The total number of full-time equivalent faculty must constitute $60 \%$ to $90 \%$ of the overall faculty. 
- The total full-time equivalent faculty who are academically qualified but who do not possess doctoral degrees should not exceed $10 \%$ to $25 \%$.

\section{Institutional Support and Financial Resources}

- Support for faculty must be sufficient to enable the program to attract and retain highquality faculty capable of supporting the program's objectives.

- There must be sufficient support and financial resources to allow all faculty members to attend national technical meetings with sufficient frequency to maintain competence as teachers and scholars.

- Adequate time must be assigned for the administration of the program.

- Upper levels of administration must provide the program with the resources and atmosphere to function effectively with the rest of the institution.

- Resources must be provided to acquire and maintain laboratory facilities that meet the needs of the program.

- Resources must be provided to support library and related information retrieval facilities that meet the needs of the program.

- The school's faculty, staff, and students must have the same opportunity for representation on the institution's advisory or policy-making bodies as do those of comparable units throughout the institution.

- The school's administrative relationships with other academic units enhance the intellectual environment and support interdisciplinary interaction.

- These administrative relationships encourage participation in the life of the parent institution.

- The school's executive officer nurtures an intellectual environment that enhances the pursuit of the school's mission and program goals and the accomplishment of its program objectives.

- Within its institutional framework the school uses effective decision-making processes that are determined mutually by the executive officer and the faculty, who regularly evaluate these processes and use the results.

- Classrooms must be adequately equipped for the courses taught.

- Documentation for hardware and software must be readily accessible to faculty and students.

- All faculty members must have access to adequate computing resources for class preparation and for scholarly activities.

- There must be adequate support personnel to install and maintain computing resources.

- Instructional assistance must be provided for the computing resources.

- Faculty offices must be adequate to enable faculty members to meet their responsibilities to students and for their professional requirements.

\section{Curriculum Content and Evaluation}

- Undergraduate curriculum should provide an understanding of perspectives that form the context for information sciences and technology.

- The curriculum should include ethical and global issues.

- The curriculum should include the influence of political, social, legal, regulatory, environmental and technological issues.

- The curriculum should include the impact of demographic diversity on organizations.

- The curriculum should include foundation knowledge for information systems application.

- The curriculum should include foundation knowledge for information science.

- The curriculum should include foundation knowledge for software and computer systems (network architectures, operating systems, systems analysis). 
- The curriculum should include foundation knowledge for information society and public policy.

- The curriculum should provide direction for future development of the field.

- The curriculum should respond to the needs of a rapidly changing technological and global society.

- The curriculum should integrate the theory, application, and use of technology.

- The core materials must provide basic coverage of algorithms, data structures, software design, programming language concepts, and computer organization and architecture.

- Theoretical foundations, problem analysis, and solution design must be stressed within the program's core materials.

- Students must be exposed to a variety of programming languages and systems and must become proficient in at least one higher-level language.

- Course work in mathematics must include discrete mathematics, differential and integral calculus, and probability and statistics.

- The oral communications skills of the student must be developed and applied in the program.

- The written communications skills of the student must be developed and applied in the program.

- The curriculum includes as appropriate cooperative degree programs, interdisciplinary coursework and research, experiential opportunities, and other similar activities.

- The curriculum should include foundation knowledge for behavioral science.

- The minimum number of total semester hour credits for the baccalaureate of Information Sciences and Technology degree should be 120 to 127 .

- The minimum number of semester hours of study in humanities, social sciences, arts and other disciplines that serve to broaden the background of the student that must be included in the curriculum is 30 to 60 .

- The minimum number of semester hours of study in the major of information sciences and technology that must be included in the curriculum is 24 to 46 .

- The minimum number of semester hours of quantitative studies that must be included in the curriculum is 9 to 18 .

- The minimum number of semester hours of science that must be included in the curriculum is 8 to 13 .

- Thirty to sixty-five percent of the credit hours for the IST degree should be earned at the degree-awarding institution.

\section{Curriculum Planning and Evaluation}

- The curriculum for the degree program should be the result of a curriculum planning process.

- The curriculum planning process should be consistent with the program's mission.

- The program curriculum should be systematically monitored to assess its effectiveness.

- The program curriculum should be revised to reflect new objectives.

- The program curriculum should be revised to incorporate improvements based on contemporary theory and practice.

- Evaluation of the curriculum includes assessment of students' achievements and their subsequent accomplishments.

- The curriculum is continually reviewed and receptive to innovation; its evaluation is used for ongoing appraisal, to make improvements, and to plan for the future.

- Evaluation involves those served by the program: students, faculty, employers, alumni, and other constituents.

Instructional Resources 
- The school/institution should provide and manage instructional technologies and related support to faculty.

- The school/institution should provide and manage student access to library resources.

- The school/institution should provide and manage student access to computer facilities.

- The school/institution should provide and manage student access to information technology.

- The school/institution should provide and manage space, facilities, and staff support adequate to meet program goals and objectives.

\section{Faculty Instructional Responsibilities}

- The faculty should be responsible for effective creation and delivery of instruction.

- The faculty should be responsible for evaluation of instructional effectiveness and student achievement.

- The faculty should be responsible for continued improvement of instructional programs.

- The faculty should be responsible for innovation in instructional processes.

- The individual members of the faculty should be responsible for currency in their instructional field(s).

- The individual members of the faculty should be responsible for accessibility to students consistent with the program's expectations.

\section{Intellectual Contributions}

- Faculty members should make intellectual contributions on a continuing basis appropriate to the program's mission.

- The outputs for intellectual contributions should be available for public scrutiny by academic peers or practitioners.

- Instructional contributions for instructional development should enhance the educational value of instructional efforts of the institution or discipline.

- Applied scholarship should pertain to the application, transfer, and interpretation of knowledge to improve IST practice and teaching.

- Intellectual contributions for instructional development should enhance the educational value of instructional efforts of the institution or discipline.

- Basic scholarship should result in the creation of new knowledge relating to the program's mission.

\section{Student Selection}

- There should be a systematic process for student selection consistent with the program's mission.

- Practices for student requirement and selection should reflect efforts to achieve demographic diversity in student enrollment by recruiting students from multicultural, multiethnic, and multilingual backgrounds.

- Adequate information concerning admission policies must be available to relevant interested constituencies.

- Student retention policies should be consistent with an objective of producing high quality graduates.

- The composition of the student body should foster a learning environment consistent with the school's mission and program goals and objectives.

- Standards for admission should be applied consistently.

- The policies and procedures for waiving any admission standard or academic prerequisite should be stated clearly and applied consistently.

- Students should receive systematic, multifaceted evaluation of their achievements.

\section{Student Support}


- Courses must be offered with sufficient frequency for students to complete the program in a timely manner.

- Courses must be structured to ensure effective interaction between faculty/teaching assistants and students in lower division courses and between faculty and students in upper division courses.

- Each student must have adequate and reasonable access to the systems needed for each course.

- Guidance on how to complete the program must be available to all students.

- Students must have access to qualified advising when they need to make course decisions and career choices.

- There must be established standards and procedures to ensure that graduates meet the requirements of the program.

- There should be a systematic plan and clear identification of the services available for career advisement and placement for students.

\section{Biography}

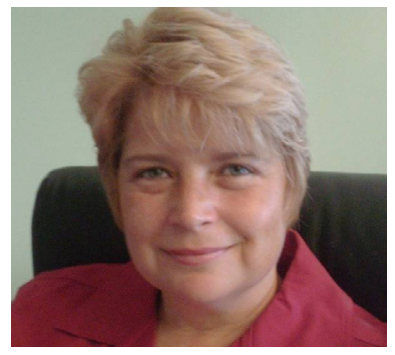

Dr. Elayne Shields-Bryant is an Assistant Professor of Accounting and Information Systems, in the College of Business and Leadership at Fort Hays State University. Her research interests pertain to Information Systems \& Technology Accreditation, Computer and Information Systems Educational Evaluation Techniques, Project-Based Learning, Team Evaluation Techniques, Electronic Commerce for Small Businesses.

Elayne received an Ed.D. in Educational Leadership from Duquesne University, (2003), an M.B.A. and M.S.-M.I.S. from the University of Pittsburgh, Katz Graduate School of Business (1996) and a dual B.A. in Business and Communications from Carlow University (1996). Elayne teaches courses pertaining to information technology, specifically Introduction to Computer Information Systems, C Sharp, Java Sharp, Database Applications, Database Design, Electronic Commerce, Java, Object-Oriented Development, Project Management, Visual Basic.Net, and System Analysis and Design. 